\title{
Connective Ecologies: Digital Animism, Computerized Ecology, and Matter in a Network
}

\section{Massimo Di Felice ${ }^{1}$ Thiago Cardoso Franco ${ }^{2}$}

Recibido: 2016-12-01

Enviado a pares: 2017-02-02

DOI: 10.5294/pacla.2018.21.4.2
Aprobado por pares: 2017-02-07

Aceptado: 2017-02-07

\section{Para citar este artículo / to reference this article / para citar este artigo}

Di Felice, M. y Franco, T. C. (2018). Connective ecologies: Digital animism, computerized ecology, and matter in a network. Palabra Clave, 21(4), 964-991. doi: 10.5294/pacla.2018.21.4.2

\section{Abstract}

This paper aims to address the processes of digitalization of territories, geographies and other communicative forms of dwelling. We take into account connective ecologies, which reveal the contemporary informational ecologies, digital animism, and the process of transformation of matter (transubstantiation). A field methodology is used through participant observation. The conclusion shows communicational possibilities that escape the traditional western models.

\section{Keywords}

Animism; communication; ecologies; digitization; transformation. (Source: Unesco Thesaurus).

1 orcid.org/0000-0003-1080-1103. Universidade de São Paulo, Brasil. massimo@usp.br

2 orcid.org/0000-0002-1774-4706. Universidade de São Paulo, Brasil. thiagofranco@usp.com 


\section{Ecologías conectivas: el animismo digital, la ecología computarizada y la materia en red}

\section{Resumen}

El propósito de este trabajo es abordar los procesos de digitalización de territorios, geografías y otras formas comunicativas de habitar. Se tiene en cuenta las ecologías conectivas, que revelan las ecologías contemporáneas de la información, el animismo digital y el procesamiento de la materia (transubstanciación). Este artículo emplea una metodología de campo, con el uso de la observación participante. La conclusión muestra posibilidades comunicacionales que escapan a los modelos occidentales tradicionales.

\section{Palabras clave}

Animismo, comunicación, ecologías, digitalización, transformación (Fuente: Tesauro de la Unesco). 


\section{Ecologias conectivas: 0 animismo digital, a ecologia computadorizada e a matéria em rede}

\section{Resumo}

O objetivo deste trabalho é abordar a digitalização dos territórios, das geografias e outras formas comunicativas de habitar. Consideram-se as ecologias conectivas, ecologias contemporâneas de informação, o processo de animismo e a transformação digital da matéria (transubstanciação). Este artigo utiliza a metodologia de campo, por meio da observação participante. A conclusão mostra possibilidades comunicacionais além dos modelos tradicionais ocidentais.

\section{Palavras-chave}

Animismo, comunicação, ecologias, digitalização, transformacional (Fonte: Tesauro da Unesco). 


\section{Ecologies without Nature}

The twenty-first international meeting on climate change, COP $21,{ }^{3}$ which took place in Paris, was a historic and decisive milestone that marks the transition from enlightenment policy, based on a social contract, which limited the rights of humans to the dimension of political action, to an ecological contract that extends the dimension of acting to non-humans (e.g., plants, climate, water, etc.). For the first time in the political history of the western world, humans have made binding decisions and have proposed goals based on the act and in consequence of the action, regarding non-human elements and entities.

The contents and the resolutions discussed at the symposium, which brought together more than 250 countries, scientists, and public and private entities from around the world, seem to have applied the reflections made decades ago by Serres (2001), which pointed out the need to move from a social contract a natural contract.

However, in addition to the apparently conductive dimension, such a contractual passage reveals some problematic issues. At the end of the dimension of political and socio-human action due to the crisis of the ecology of the polis, its modern-industrial and the polluting form of the nation-state (from the perspective of the participants of COP21 and to all the disciples and followers of Michel Serres, Bruno Latour, Isabelle Stengers, Serge Latouche, etc.), there is an urgent need to create new contractual dimension between the human and non-human, that is, between citizens, nations, and the forces of nature.

This urgency would increase as the extension of the political and parliamentary logic (including the parliament of things of Serres and Latour) to the entire planet, in its new live configuration, represented as Gaia. A first problematic finding is whether this enlarged parliamentary and political dimension would not be the continuation and extension of a new for-

3 The $21^{\text {st }}$ Climate Conference, held in December 2015 in Paris. The acronym COP stands for Conférence des Parties ("Conference of Parties," in English) or even Conference of the Signatory States. The event gathered authorities from around the world to discuss issues relating to climate change. 
mat of political, urban, and anthropomorphic action that would implement the anthropocentric political dimension and reason to all that exists. In other words, Gaia would be a new agora, in which humans and non-humans would sit to reach an agreement, contractually regulating the relevant acting.

A second problematic point concerns the origin of this new contractual form. It considers the question of how to establish a political dialogue with the climate, the ozone layer, volcanoes and tsunamis. Latour (2004) does not seem to be able to offer a proper explanation to this question, but the indications of spokespersons as the only way of achieving a parliament of things indicate a relapse into the modern political and anthropocentric dimension.

Since the composition of the common world, now that it is no longer a given from the outset, has to be the object of a debate, the only way to recognize the "citizenry" within the collective that may be relevant for public life is to define the collective as an assembly of beings capable of speaking. Political philosophy traditionally required discussion to take the place of violence; now, it also has to be able to replace both silence and the nondiscussable. Why might this vague word "discussion," borrowed from the fracas of human assembly, serve to redefine political ecology, which bears precisely on beings that do not speak, that belong to the nature of mute things? Politics talks and palavers; nature does not, except in ancient myths, fables, and fairy tales. Yet a slight displacement of our attention suffices to show that nonhumans, too, are implicated in a great number of speech "impedimenta". This observation will allow us to modify the meaning of the word "discussion," shifting it away from the political tradition toward what will become the future ecological tradition, even as the word retains for speech, for the logos, the central place it has always held in political philosophy. (Latour, 2004, pp. 62-63)

To overcome the limitations of such reflections that seem to clash, particularly with the perspective of Michel Serres and Bruno Latour in a parliamentary and contractual dimension, it seems to us that it is necessary to doubt the philosophical concept and, therefore, the concept of western ecology. ${ }^{4}$ In fact, social sciences seem to be based on an ecological concept

4 By this, we understand the etymological meaning of the word ecology, from the Greek Eאo- $\lambda \circ \gamma \circ \varsigma$, as the discourse on the environment and its proposed scientific sense in the modern era of biological sciences. 
derived from the myth of creation of western tradition in the Bible and the Greek philosophical tradition. What is common in these various conceptions is the belief in the separation of humans from nature and, therefore, its ontological distinction as a single entity.

Whether in the biblical tradition, expressed in the creation of the human in the image of God, or in the concept of naturalist philosophers, which depicts nature as $\varphi v i \iota$, from Tales to Socrates and Plato, or that of the being of Parmenides, the human entity is perceived as distinct from nature and the other elements that compose the tangible world. This separation, which assumes ontological dimensions, will be perpetuated in western thought, assuming the dimensions of humanism (of Saint Augustine) in the tradition of the Middle Ages, assuming the form of the rational subject (of Descartes) and the social actor (of Max Weber) in modern tradition.

In the tradition of pre-scientific western philosophy, ecology assumes, with few exceptions, the dimensions and meanings of the human habitat, identifying itself as a human ecology, which makes the är $\theta \rho \omega \pi \circ$ (ánthropos) the measure of all things. ${ }^{5}$ The human narrative developed by western thought (Di Felice \& Pireddu, 2010) ${ }^{6}$ does not permit the description of the contemporary passage of political urban and national ecologies to those connected and interdependent of Gaia (Lovelock, 2007).

In this way, identifying the constituent elements of a non-western ecology that overcomes both the centrality of the human being and the subsequent determination of realities around it (nature, technics, inorganic material, etc.) is, in contemporary contexts, a challenge for the studies of various areas.

Next to the planetary ecological emergency that concentrates the interest of the various spheres of knowledge, studies of ecological forms without nature, in a non-western perspective, may constitute a specific field of

5 The idea of man as the measure of all things becomes in the western European culture a universal concept that since Protagoras has passed through the millennia and arriving at the Vitruvian Man drawn by Leonardo da Vinci.

6 Di Felice and Pireddu (2010) present, in a transdisciplinary perspective, the various meanings assigned in recent times to overcome the humanist narrative-union on the human. 
research of communication theory, as a result of the connective and digital character on which contemporary ecologies are based. After the Internet of Things and various forms of digitalization of the territories, conducted by informational systems and by different types of georeferencing of the localities, the result is an essential process for the studies of the territory and the environment, which takes into account the connective and communicative dimension.

The assumption of this approach begins with the search for a connective rather than anthropocentric idea of ecology, ${ }^{7}$ alongside the proper definition of biological science of ecology, which must be considered as an indispensable reference for understanding its interdependent and trans-specific dimensions. We propose, then, two extreme examples, which have ecological models without subject or object, and which are therefore different from the representative logic of European and/or western externalities.

One refers to a particular type of communicative ecology existing among the Krahô Indians, which expresses a way of animism in which the various elements of reality communicate naturally. The other one refers to the appearance of a kind of materiality arising from the advent of new forms of technology of connection able to achieve and to interact with stones located in other planets of our solar system. In their specificities, the two examples show the appearance of an ecology without nature, but one that is networking, collaborative and, consequently, in continuous redefinition.

\section{The Rocks of Mars and the Digital Connection}

The images of the soil and sky of Mars, divulged in recent months by the different probes launched by NASA that landed on the red planet, reveal an unprecedented dwelling condition characterized by the perception of "nature," which we inhabit through the mediation of technologies and devices that allow us to perceive its vision and knowledge.

7 Di Felice, Torres, and Yanaze (2012) remind us that the word comes from Greek oikos (meaning "house" or "habitat") and logos (meaning "speech"). The term was coined in 1866 by E. Haeckel, a biologist follower of Darwin's theories. The goal was to study the relationships of the various organisms with the outside world, both those with an organic environment as well as those with an inorganic environment. 
We cannot walk on the rocks on Mars, but we see them and we can analyze their fragments.

We have never been to Mars, but we can see it, the composition of its ground, its temperature, the mountains and, curiously, analyze the horizon through the cameras transmitting the view of its landscape in real time. We are far apart, but at the same time we delight in watching the show between the colors and forms of their rocks. This unprecedented ecology is the expression of an atopic dwelling condition (from the Greek, a-tops, a place difficult to define, a strange place, a place out of place, an unspeakable place).

We do not only inhabit our planet and its biosphere anymore, but an endless universe, consisting of a multitude of galaxies in motion and, therefore, impossible to dwell ${ }^{8}$ in, according to the concept attributed to dwelling by western culture. In the same way, the materiality of the rocks of Mars, through the instruments of identification, have a consistency, shape and weight, but not tangibility, and they present themselves to us as a singular matter, the bearer of a new type of consistency that is perceptible only through technology.

The term atopy $y^{9}$ reminds us of the need to rethink the relationship between ourselves and the environment, no longer starting from a logical opposite (man/nature) or frontal (nature as landscape), but from a reticular and connective prospective, which can become useful in interpreting how our dwelling condition has changed with the advent of digital networks, Wi-Fi spaces, and diverse mobile connection devices.

The idea of a space-net leads us to overcome the conception of the existence of a "natural" space and to replace it with that of a relational territoriality, built through the fertile synergy of individuals, connections, information, databases, and territoriality.

This perspective reveals the ecological dimension of the dwelling condition, which is proposed as a distant category, either from the logo-or an-

8 About the concept of $d w e l l i n g$, we refer to the contribution and the meanings attributed to Heidegger (1971), especially in the text "Building, Dwelling, Thinking."

9 The term atopy comes from the Greek word $a \tau 0 \pi \circ \varsigma$, which means "place out of place, place atypical, place indefinable." This category was presented by Di Felice (2009). 
thropocentric perspective, of that object-or techno-centric (the Internet of Things), thus becoming the expression of a reticular epistemology that connects its members by altering them.

More than the perspective of object-oriented ontology, Harman (2011) (who thinks of matter as objective specificity, or the correlative dimension of Meillassoux (2008), which constructs its own explanation, unlike Harman, from the existence of the sensitive through the relation of the subject with this, and in a prospective still decidedly Cartesian) the prospective atopic develops from the emergence of a new type of info-matter that is at the same time image, pixel, informative circuit, information and materiality. There is not subject and object anymore, everything is linked and complements each other.

Furthermore, if we think about structure of matter, such as the architecture of the DNA double helix, the deoxyribonucleic acid or the studies of particles in nuclear physics, the non-divisibility between the structure of matter and the information is clear to us. However, the advent of digitalization has imposed a qualitative leap, which we briefly can indicate as a consequence of factors: first, we have information, understood as the process of decomposition through binary sequences and the recomposition of the same subject in bits (this process is configured as a transubstantiation, i.e., as that alteration of the same substance or modification of the same nature); and second, the connection process that, through the digital architectures of networks, circumscribes everything, distributing it in the networks and conferring to the matter its own properties and communicative dimension.

It is not, therefore, only the RFID tags, which through the radio system identify objects and network them (internet of things), but the whole process of scanning presents as a change of substance and as, ultimately, the coming to be of a new kind of materiality. If the internet of things puts emphasis on the communicative becoming of things, atopy poses the alteration of the status of the nature of the thing itself and the need to think of a new type of ecology and of habitation. When you get to know something new your nature changes and the new thing becomes a part of you. Everything is linked, subject and object are the same thing. 


\section{Fieldwork and Analysis: The Krahô Digital Animism}

The Krahô inhabit the northern region of Brazil. There are twenty-eight villages in an area of 302,000 hectares of scrubland in the northeastern part of the state of Tocantins. Their villages have a circular shape and comprise a network, but it is not an association. Considering the perspective of transubstantiation, the reticular Krahô condition seems to exceed the aggregative concept to present another "form of communicative dwelling" (Di Felice, 2009), a fact that we will see in the following pages.

To continue our example, we begin by telling the story of the small hatchet, the Kàjre. We decided to search for the spiritual narrative of the hatchet, because it is a clear passage from the communicational human/ non-human interaction within the Krahô ecology.

There is a small hatchet among the Krahô named Kàjre. ${ }^{10}$ In accordance with the practices of the natives, it has the ability to sing and to harmonize the village. The present text seeks to address a bit about the history of this small hatchet and how communication occurs in this animistic environment.

In 1986, the Kàjre became very well known when a group of Krahô went to São Paulo to retrieve it. It had been taken by the anthropologist Harald Schultz decades before and was incorporated into the collections of the Museu Paulista of the University of São Paulo (USP), where it was kept for about 40 years, according to the historical archives of the newspaper Folha de São Paulo (1986a). In the same year, the hatchet was returned to the Krahô by the then rector of the USP, José Goldemberg.

10 The word Kàjre ( $k a j>$ Ax -re > indicates only the diminutive Krahô, and not the gender) appears in writing in various forms in literature. However, we decided to adopt the version of the literacy book of the Krahô tongue, according to Albuquerque and Krahô (2013). In the citations of this text, the term may appear written differently, but this is because of the rigor with which the original publication was made at that time. It is important to say that Morim (2013) and Melo (2010) indicate the Kàjre as a male object. However, the present fieldwork revealed to us on July 21, 2015 that the name Kàjre is understood among the Krahô of the Manuel Alves Village as female, both in Portuguese and in the Krahô language. The information was confirmed by Renato Yahé and Roberto Cahxêt, both responsible for the Krahô grammar and dictionary, respectively. The reason for the disagreement of the gender of Kàjre is not yet known. 
Part of that history occurred when the then chief Pedro Peño discovered the whereabouts of the Kajre and decided to bring it back with the presence of other natives, who remained approximately ninety days in São Paulo, hoping that the estimated sacred hatchet would be returned.

I am older and I see that the new Indian loses the ritual, custom, and I came to the capital São Paulo to bring Kyiré back. You do not know what Kyiré can do. She is for marriage, for baptism of the boys. That's why it matters. (Education and Science, 1986a, p.6)

The situation divided opinions. Melo (2010, p. 88) recalls that the then rector of USP, physicist José Goldemberg, was initially opposed to returning it, because it was an "object of humanity's patrimony." However, the situation gained the support of the newspapers and the pressure to return it increased, with the participation of indigenist Fernando Schiavini and anthropologist Sergio Domingos, who supported the return of Kàjre to the Pedra Branca village.

Melo (2010) also shows that, among the arguments of the Museu Paulista was that, if returned to the village, the hatchet would be lost again. This fact is very interesting because the versions of the myths of the early Kàjre show the losses and conquests of the hatchet. For the Krahô, the Kàjre is a conquered actor that has passed through several owners, that sings and harmonizes the village. The mythology of the hatchet is marked by loss, theft, and recoveries, a fact that is confused with its own story.

On May 29, 1986, Folha de São Paulo divulged another material about the impasse and the attempt of a curious agreement. The report was that:

Goldemberg said yesterday that the proposal is from the Department of Social Sciences of the Faculty of Philosophy, Literature and Human Sciences (FFLCH) and the Brazilian Association of Anthropology. "In exchange for the small hatchet, the Indians will make a replica to be displayed in the museum which would provide a proper explanation to the public. It is a quite reasonable proposal," said the rector. (Folha de São Paulo, 1986b, p. 40, my translation)

The Krahô answer appeared in the same issue, through the voice of a friend of Peño, Aleixo Pohi, chief of the marsh deer village. 
The Indian Krahô, Alexo Pohi, leader of the marsh deer village, said that the proposal will be well received; however, he makes the proviso: "We want the museum to provide us with the mud to produce a small hatchet because we do not know where to find it. The cable and the ornaments we will place." (Folha de São Paulo, 1986b, p. 40, my translation)

During the negotiations, the division of opinions among the teachers led to the publication of the article "A Universidade e a machadinha" in Folha de São Paulo, on May 2, 1986, signed by the professor in the Department of Anthropology, Eunice Ribeiro Durham, who argued that the hatchet had not been stolen by Harald Schultz and that she favored its return.

For the Krahôs, the Kàje is a sacred and mythological being. Morin (2013, p. 186) recalls that the hatchet does not emit any sound, but that it is used in rituals, along with "musical companions." Among them are: cuhtoj (maraca), $x y$ (belt with gourds, which presents rattle sound), kô po (wooden stick), among others. The hatchet is a "being-singer."

To better understand this dynamic, fieldwork was performed in July 2015 in the Manuel Alves and Pedra Branca villages. The purpose, through participant observation, was to gather perspectives about the Kàjre and the communicational process involved. From this perspective, we focus on the following topics: the spiritual condition of the Kàje and the information passed through generations; the communication condition; and transubstantiation and the Kàjre in a network.

\section{The spiritual condition of the Kàjre and the information passed through generations}

The Kàjre is in the Pedra Branca village. The fearless Pedro Peño died in 2002 at the age of 95, and left the small hatchet to his son, Martin Peño, who is now over 60 years old. During the fieldwork, already in the State of Tocantins, we went from the Manuel Alves village to Pedra Branca, which are about $30 \mathrm{~km}$ away from each other. Roberto Cahxêt was our intermediary in the encounter with Mr. Martinho. 
Martinho told us a little about the origin myth of Kàre. The story that follows below is a summary of the narrative that is still in the process of translation, since everything has been collected in the Jê language. It is important to state that there are other versions in the village.

A long time ago there was a very good hunter. I can't tell you the time. His name was Hartant. One day he went out hunting with other mehĩ (Krahô Indians). After a day without finding anything, they decided to stop at the irom (forest). I don't know where. Suddenly, they all heard a song. Then they asked: "Who is singing, Hartant?" It was then that Hartant said: "It's the small hatchet that is with its owner. They are the ones singing." I do not know who the owner is, but Hartant found them. He went alone, he left the other mehĩ and went alone. He asked everyone to wait, that he would come back with the hatchet. When he arrived where they were singing he asked for the hatchet. Then the owner said that he was not going to give it that night, only the next day. The hatchet continued to sing the whole night until dawn. The owner did just the way he spoke. In the morning he offered the hatchet, but asked: "Hartant, I have two small hatchets. The small is the female and the larger is the male. Which do you want?" Then Hartant asked for the male and left the other, but before he had to learn all the songs to sing along with the hatchet. He was the one who taught the songs.

During the rituals, the professional singer hears the hatchet and simultaneously transmits its singing. That is why it is a "sing-along" and not a spokesman, according to Latour (2004). Only some Krahô know how to sing with the Kàjre. Mr. Martinho let us hold it for a few moments and we agreed to return in 2016 for the Potato Feast, when the small hatchet is usually invited to sing with the Krahô. In truth, when the hatchet sings, it passes along teachings and learnings of everyday life.

Mr. Martinho is considered not to be a common narrator. He is a wise old man in this and other stories. When we arrived in the village, the younger soon tried to bring us up to his $i k r e ́$, to his house. Young people do not tell many stories among Krahô. They always show us the elders those who have lived. The information is passed on by oral tradition over time.

Note that the narrative of the hatchet goes through a mythology that is intertwined with factual history. The Kàjre seem to incorporate a being 
that needs to be conquered, lost and found to meet their fate. These meetings, missed meetings and re-encounters are present both in the mythology and in as the facts that occurred in the 1980s.

The next day we spoke with the chief of the Manuel Alves village, Dodanin Piikẽn. He wanted to know about our conversation with Mr. Martinho. We told him how everything went, and the chief said he was very happy for the Krahô, who are telling their stories, because "None who go there understand how the hatchet works. It has to circulate and only one Krahô can 'sing-along' with it. Only the champions of the games, the good hunters, men of pure heart can touch it." ${ }^{11}$

We were silent during the explanation. On the way back, Roberto was asked: "If only a few sing along with Kàjre and only the champions play on the hatchet ... How could a (non-Indian) kupẽ manage to hold it? Roberto's explanation was straightforward: "you do not speak her tongue, to understand what she sings." Now a kupẽ does not have the world to understand the hatchet. It seems that only one Krahô can successfully tell his story and it is in this sense that communication among the Krahôs includes non-humans."

\section{The communication condition}

While walking through the villages, it is common to hear stories in which animals communicate among themselves. There is a sort of a spiritual ecology in the village, in which non-humans communicate. In the Krahô perspective, animals may assume the position of guides to teach. According to the reports collected, the animals are also people; the only thing that changes is the body. Viveiros de Castro (2013) already addressed this subject some years ago.

This ethnographic reshuffling motivated by the conceptual maps leads me to suggest the expression "multinaturalism" to designate one of the patterns of Amerindian thought in relation to modern "multicultural cosmologies": while these are based on a mutual implication between the oneness of nature and the multiplicity of cultures-

11 Conversation with Dodanin Piikẽn on October 23, 2015. 
the first guaranteed by the objective universality of bodies and of substance, the second generated by the particularity of subjective minds and meanings - , the Amerindian concept would assume, on the contrary, a unity of spirit and a diversity of bodies. The "culture" or the subject would be here a form of the universal, a "nature" or the object a form of the particular. (pp. 348-349, my translation)

What Viveiros de Castro (2013) is showing is that the culture among the Amerindians of the Amazon region is just one. What changes is the nature of the bodies. Among the natives of the Amazon, all humans and non-humans see the world. What dwells in the other is the spirit, as well as how the other sees us as a spirit.

The other is no different when they are spirit-what is different is the body. Animals conform to the same categories and values as humans, "their worlds, like ours, revolve around hunting and fishing, the kitchen, and fermented beverages, of the first crusades and war, the rites of initiation, the shamans, heads, spirits...”(Viveiros de Castro, 1996, p. 127, my translation).

However, Viveiros de Castro (1996) points out that the bodies in the multiple natures also see from distinct perspectives. What to man is blood, for the jaguar it is cauim, ${ }^{12}$ or that which we see as a region of clay, for tapirs it is a large ceremonial house.

Among the natives of the Amazon, the conversation goes beyond the space of the courtyard or the common and public places. It also occurs in the encounter, in the forest, among those who are people. The mythology generally shows a meeting between a man (always alone) and a being who shows herself primarily as an animal or as a person who

[...] reveals itself as a spirit or a death, and speaks with the man (the dynamics of this communication is very well analyzed by Taylor 1993a). These meetings can be lethal to the interlocutor, who, overwhelmed by the subjectivity of non-human, passes to her side, transforming into a being of the same species as the announcer: dead, spirit or animal. (Viveiros de Castro, 1996, p. 135, my translation)

12 This is a type of fermented beverage made from cassava, corn and fruits. 
Viveiros de Castro describes the encounter and dialogue in the process of Amazonian shamanism. Given the special features, it cannot be said that there exists a reproduction of the shamanic model, of Viveiros de Castro, among the Krahô.

However, there are private shamanic divisions, namely the figures of the sorcerer and the healer. According to Melatti (1963), the figure of the wizard $^{13}(\mathrm{kai})$ tends to be hidden. What appears with greater frequency is the category of the healer or wayaká. The healer apparently learns to prepare medicines from an experience with the elders and/or in conjunction with non-humans. In the case of communication with the non-human, the exchange of information always occurs when the native is alone in the forest (irõm), as indicated in Viveiros de Castro's quote above.

Among the Krahô, there are clues for the perception of multinaturalism. However, among these natives, the multiple natures seem to be blended with the notion of culture and, in this sense, the term ecology seems better. However, it is a non-western ecology. Thus, humans and non-humans are considered "people"; what changes is the nature, and soon so does the perspective. Therefore, there is no consensus of a nature, an idea which is employed by the West.

Note how a conversation about one of the versions of the creation myth of Kàjre is recorded. On that occasion, Melo (2010) talked with two Krahô, one of whom was a padré (one who knows the myths and rites of the village).

When I asked him who was this "owner of kàjré," the padré hesitated, and Pascoal, who heard the conversation, suggested that it was the monkey. "Yes, but it's also people," answered Kraté to the cacique and, returning to me, "It is a person, but I don't know who he is, from where he is. Mẽhĩ does not know. And also Hartant, I do not know whose son he is. He lived where kàjré was, he knows everything..." He said he had come to sing with the Krahô, married there and afterwards led the Krahô to where he was born, for the tribe where he had kàjré, and asked for the owner of

13 The Krahô see the Sorcerer as the one who uses shamanism for bad practices. 
this small hatchet. But this is really old... More than two thousand years... (p. 79 , my translation)

There is a complexity here. The monkey would have been the Kàjre's first owner. A particular form (the monkey) owns in another particular way (the Kàjre), that now lives with the Krahôs. Kàjre is an exception, in which communication is collective. To the Krahôs, the Kàjre is a "Being" who sings together, that is, a particular form endowed with spirit. The hatchet is not made or even created by man; it lives together with humans and non-humans. The Kàjre is an exception, in which communication is collective. For the Krahô, the Kàjre is a "being" that sings, that is, a particular form endowed with spirit. The hatchet is not manufactured or even created by man-she lives with humans and non-humans.

The moment of the ritual and the particularity of the form are taken seriously among the Krahô. Morim (2013) reinforces the existence of other small axes that were found in the fields, the fruit of ancestors; however, only the Kàjre would be authentic. Melatti had already noticed that in the 1970s:

Since 1962 I have never seen any khëiré in use by craôs. Judging by some information, it seems that the modern craôs do not know how to make a stone blade; they modify axes made by people who have already disappeared, then make the trim with a cable and ornaments. The khëiré is not used as a means of cutting or weapon. It is simply carried by the man who sings. It is hung under his arm, well next to the axilla, or tied by the cable, while the singer's arm is raised, but with the elbow flexed, so that the cotton pendants fall along her forearm. (Melatti, 1974, p. 11, my translation)

In this sense, it does seem correct to interpret it as just an object. When Peño says, "She is for marriage, a baptizer of the boys. And that is why it is important” (Folha de São Paulo, 1986a), she escapes from simple management of the Kàjre. A small hatchet to sing along with a professional, ${ }^{14}$ Krahô receives the status of a singer, a being who sings along with the other humans and non-humans.

14 It is very common to hear the word professional among the Krahô. It has nothing to do with the profession or employment, but with the work itself. You can have an accomplished hunter who, however, dominates all corners of 


\section{Transubstantiation and Kàjre in network}

The Krahôs have been accessing digital social networks since 2013. Access is done by cell phone in the city of Itacajá, Tocantins, or in the village Manuel Alves, from where the signal comes. One can see how easily they find themselves in the digital environment. Figure 1, reveals the mêkarô of the hatchet and exposes the Kàjre, which, when digitized, changes substance. She goes through a digital transubstantiation.

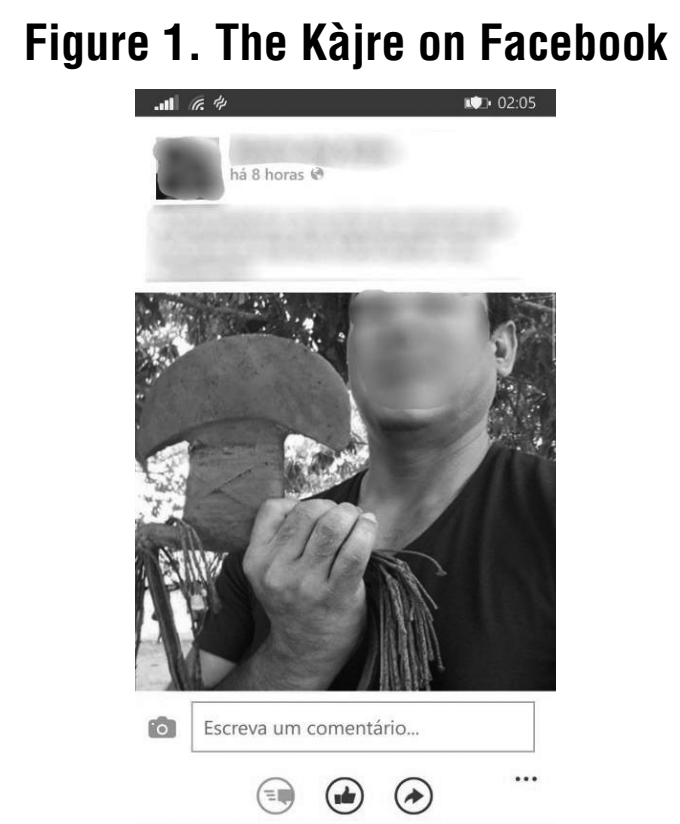

Source: Adaptation of a Facebook image.

However, the transubstantiation can be perceived differently among the Krahô. In this sense, we must take into consideration the mẽkarô, which can be understood in general terms as the spirit and/or the spirit reflected. The reflection of the body in the water reflects what is contained in the body, so all those who are "people" are spirits that transit and can be reflected.

The word mêkarô was adapted for photography, but it is much deeper than the image simply captured. Researcher Manuela Carneiro da Cunha 
(1978) explains the term better when speaking of the vital principles among the Krahô. The first vital principle is the breath and:

A second vital principle is the karõ (plural mekarõ). It inhabits the body, although it is absent in dreams and in diseases; it survives men, and it is he who will settle among the dead and there lead an insipid and diminished life there. Perhaps because of this karõ counts among other senses the dead, which is more common when used in the collective form (mekarõ), a bit like we use the terms "spirits or souls of deceased persons." The significance of karõ, however, seems to be much more widespread: the term encompasses in their denotata the photography, the reflection, the whole "body image." But not only that: the karõ can assume, even while connected to the host body, a different appearance of this body in which he dwells: it has been described to us, when we were told about the reinsertion of a karõ tramp, as a blank object, about the size of a finger, similar to a small frog (prokayê), something much more manipulable by the healer. (Carneiro da Cunha, 1978, p. 10, my translation)

In another point, Carneiro da Cunha (1978, p. 115) shows that the Khraô can assume a freer form during the transition process. If first he was a large animal, after death, he may come to be a stone or a termite. The possibilities of metamorphosis are manifold.

In this sense, we went through an interesting experience at Aldeia Pedra Branca: A Krahô approached and asked to take a photo. We said that we had just taken a selfie, a self-portrait. He said he saw only mẽkarô. The term mêkarô is related to a complexity that goes totally against what is meant by selfie. The translation of our disconcert was briefly: At the same time that the Western conception saw an "I" as flesh, he saw the "I" as "spirit" and/or mëkarô.

Costa's (2013) thesis shows that the mental image of the place where he lives among the Krahô is also directly related to the mêkarô. For example, if someone asks for a Krahô to draw where he lives, the mental map reflected on paper is the Pjê Mẽkarô (the place of the spirits). Not the spirit as a category equivalent of the mind (as a science of the spirit), but what inhabits the body of the other. 
The Pjê seems to be a large territory inhabited by spirits housed in a diverse ecology and who are organized in consonance with the form of reticular villages, a spiritual place in transit. The transit passes through a reticular conception. Each village knows the limit of its territory and the divisions are virtual-there is obviously a degree of volatility in these divisions. In this context, the new villages emerge as islands, fruit of the divergences.

Costa (2013) allows us to think about how this ecology is constituted, with geographical information from satellites and the use of mental maps (Figure 2). On the left, we have satellite images that transform the territory into something digital and, on the right, a map that was partly designed as a mental map.

\section{Figure 2. The non-digital Krahô network}
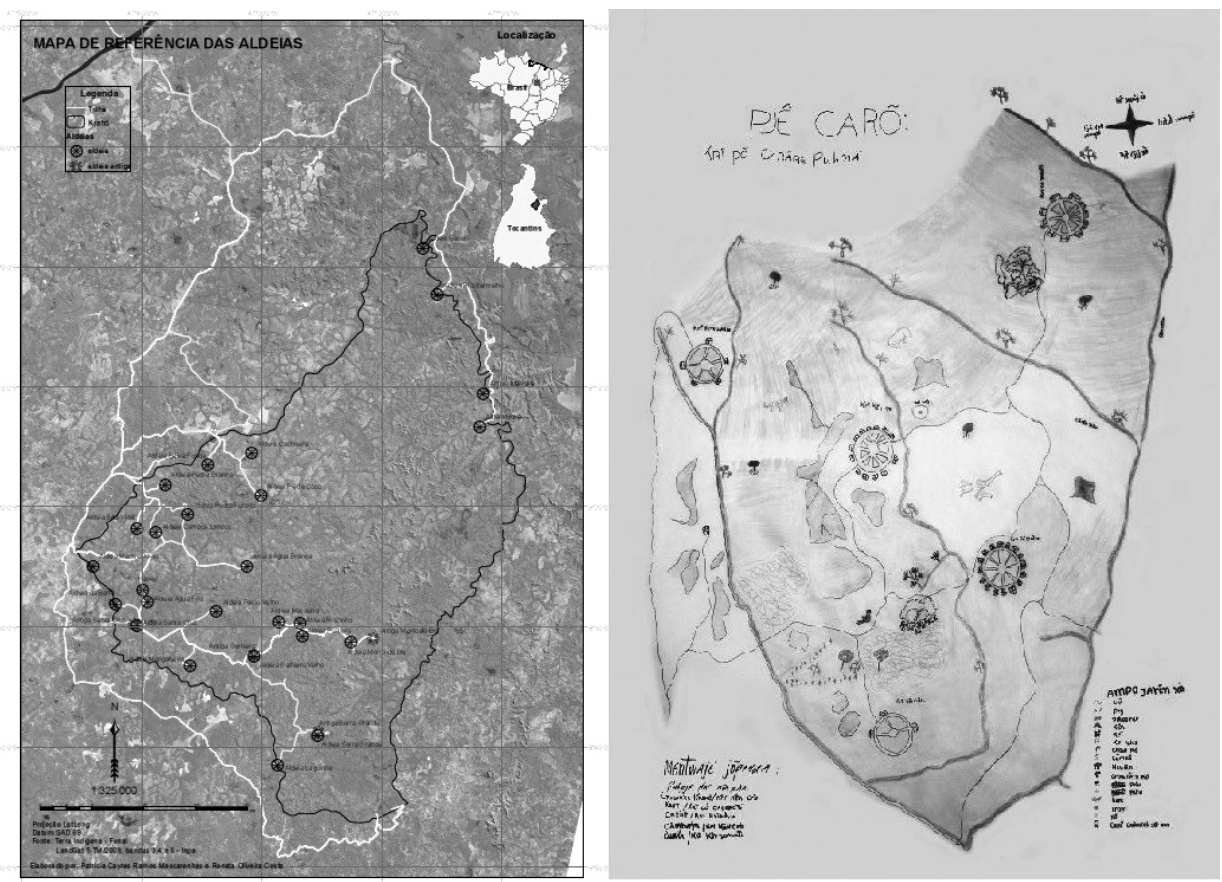

Source: Adapted from Costa (2013).

On the left side, we have an image that based on the gathering of information, in the model of the "stones of Mars," as already mentioned. On the 
right, we also have transubstantiation, but according to mẽkarô standards. We must emphasize the western influence of researcher Costa (2013), because the Krahôs do not have the rose of the winds. However, the design reveals the non-western ecological harmony between man and nature. The village is connected to what is around you.

Thus, in Figure 2, you may have a notion of the ecological Krahô formation. In the satellite's image, the yellow lines represent the trails, which form the non-digital native network in the midst of scrubland vegetation. In the mental map, we can have an idea of how the Krahô graphically understand their own ecology.

In that first moment, and based on experience, what we see is that the process of unveiling that reflects in the village offers possibilities for a transit into a network. The territory, even with western interference, preserves much of the Krahô connection and seems to be the mirror of a reticular formation and of indigenous knowledge, which goes beyond the classic western sense.

The Krahô reticularity puts at stake the understanding with humans and non-humans. Before being digitized, the Kàre is already in accordance with another reticular form, which is the Krahô ecological formation itself and/or a particular communicative form of inhabiting the world. The hatchet in finding that the digital seems not to lose its psychic importance. There is reverence and respect in the comments of the posts in which it appears, yet the substance is different.

\section{The connected materiality and the digital ecologies}

The digitization process, the transubstantiation and the connectivity makes it impossible to think of things and objects as presented to us by western philosophy, that is, as foreign and incommunicative material. Consequently, the entire epistemological architecture of European thought, from Plato to Descartes, which has always represented the environment, the technique and things as an externality, with very few exceptions, should be discussed. 
How do we narrate this new kind of connected materiality, reachable, knowable and existing only through the technologies, whose substance is something in the middle of the path between matter and information?

The first point of departure proposed is an ecological approach. Since we are speaking of a connected materiality, we cannot analyze it in itself, starting from their various properties and declinations. It also seems necessary to avoid both the essentialist Kantian approach of the thing itself, and that Platonic-interpretative of its philosophical representations, more specifically the harmanian ${ }^{15}$.

However, at the same time, we believe it is absolutely essential to overcome the interpretation that describes matter and the thing as a black box, that is, as a field of human interactions, technology and materials that is articulated in networks, determining the substance at each time and, therefore, replacing in the social and aggregative interactions its very essence, considering the positioning along the trajectory of Bruno Latour and Michel Callon.

Such an approach easily overlooks the fact that, at the time of the associations and the aggregative processes that should establish and identify the hybrid nature of the materiality, the transformation, that is, the alteration of its substance has already happened as a result of a digitalization process and of a change techno-substantial, which occurred prior to the set of associative and social interactions.

On the contrary, it is necessary to emphasize the connective character, rather than the associative one, of such ecology. Digital ecology cannot be interpreted only as an associative ecology, resulting from all the interactions in networks, as proposed by Latour's (2012) Actor-Network Theory (TAR), because it is a kind of ecology that is not realized in the sphere of the interpretive dynamics of controversies, nor those of the associative dynamics of the various actors.

15 Concerning the work of Gilbert Harman. 
The connected materiality and the digital ecologies are forms of transformation. Change the substance, the nature and the ecology and, as a result, it no longer presents itself only as processes of relationships and interpretations, but more so as a change in the proper dwelling context where they are given.

Digital ecology is not a contractual and enlightenment ecology (along the lines of Thomas Hobbes and Jean-Jacques Rousseau) or a legal (of the Kantian type), or political (Latour, 2004) or cosmopolitan (Stengers, 2007) ecology. However, digital ecology approaches the idea of community developed by Agostinho (2002) according to which the community is not something that can be realized, as this already exists for all creatures as a result of creation. Therefore, connective materiality, while digitized and as an expression of a transformation, is part of an atopic ecology.

This ecology is not something natural, or the mere result of human activities, or a mechanical product of technique, but something that forces us to redefine the same idea of interaction between this informative material, digital technologies, the environment, etc. The new connected materialities are, from this point of view, the forming form of ecological dynamics, which are, at the same time, artifacts and results.

Thus, the materialities no longer belong to a world of objects and subjects, or the aggregate and frontal environment of emerging networks, as expressed by the Actor-Network Theory. They belong to the world of a-dynamism, of digital connections in a network and the world In-sein of the Heideggerian event. In this sense, Heidegger (2012) points out that the being is not beyond us, nor in us, nor around us; on the contrary, we are in it as an event.

\section{Conclusions: Ecology without Objects and Non-Objects}

The digitization process of the territories and geographies has contributed in the actual contexts of geographical information systems (GIS) of mobile connectivity (Wi-Fi, 3G, 4G, GPS, etc.), to produce a new ecological 
culture. The geographical informational systems attach to the place and the things a new dimension that cannot be any more defined in geographical location, topography and material terms.

On the other hand, it should not be delimited by the perception of the subject, but by a set of information flows and interactions that connect place, things, database, linking information and changed continuously, according to the circuits chosen or crossed by people, information flows, data, the sense of place.

Location and things, thus, are no longer objective data or something that presents itself as landscape or subject (ob-jectum), but they become a plurality traversable and habitable in various ways (Di Felice, 2009). Thus, it is understood that, from this point of view, the geographic information systems do not belong to the category of locative media (Lemos, 2008; Santaella, 2008), or to a set georeferencing techniques, which simply describe, in a superficial manner, the instrumental dimension — that is, the effect produced and expected.

In contrast, in a perspective of networks of connections, green technologies, materialities and things connected, informational systems in geographical terms, Wi-Fi networks, and Google Earth constitute processes of change in the forms of dwelling, which in a way is analogous to the video camera analyzed by Benjamin (1987), the idea of a thing expressed by Heidegger (1971) and that of the transduction of Simondon (2009) contribute to making-space. During the making-space, one discovers (unverborgenheit) and sometimes one covers (verborgenheit) what is happening. It is a simultaneous process.

Heidegger (2003) reminds us that this aspect of the making-space easily escapes us, and, when it comes to considering, it is always particularly difficult to determine when the technical-physical space predominates as that which must be renewed in advance of each characterization of the space. 
The digitization of territories, roads, forests and things changes not only our way of travelling and accessing places, but the very nature of the place and even our dwelling condition. It no longer makes sense to speak, at the same time, either of the virtuality of places and things, or of locations and material things, because both are expressions of a perceptual, landscape and frontal representation of the territory and nature.

The digitization of things and the territory, by multiplying the forms and the dimensionality (space of a-dimensions) not only cancels the objectivity and the virtuality (understood as its opposite), but introduces a connective dimension of dwelling expressed in Di Felice (2009) as atopy, in opposition to the concept of non-place proposed by Augé (1994).

The things connected are atopic while expressing a particular condition, defined by Heidegger (1973) as stateless, that is, how open the relationship is with things, such as the loss of the sense of place. In our contemporary world, we experience a particular type of statelessness, which at the same time that it distracts us from locality and material things, it connects us to the bottom of the oceans, to tropical forests, to biodiversity and to the stars.

\section{References}

Agostinho. (2002). La città di Dio. Roma, Italy: Città Nuova.

Albuquerque, F. E., \& Krahô, R. Y. (2013). Krahô jõ ihkàhhôc Kryjre me cati. Campinas, SP: Editora Pontes.

Augé, M. (1994). Não-lugares: introdução a uma antropologia da supermodernidade. São Paulo, SP: Papirus.

Benjamin, W. (1987). A obra de arte na era de sua reprodutibilidade técnica. São Paulo, SP: Brasiliense.

Carneiro Da Cunha, M. (1978). Os mortos e os outros. Uma análise do sistema funerário e da noção de pessoa entre os índios. São Paulo, SP: Hucitec. 
Costa, R. O. (2013). Na trilha dosTimbira: sustentabilidade e territorialidade Krahô (Doctoral Thesis). Center for Sustainable Development, University of Brasilia, Brasilia.

Di Felice, M. (2009). Paisagens pós-urbanas: ofim da experiência urbana e as formas comunicativas do habitar. São Paulo, SP: Atlas.

Di Felice, M., \& Pireddu, M. (2010). Pós-humanismo. As relações entre o humano e a técnica na época das redes. São Caetano do Sul, SP: Difusão.

Di Felice, M., Torres, J. C., \& Yanaze, L. K. H. (2012). Redes digitais e sustentabilidade: as interações com o meio ambiente na era da informação. São Paulo, SP: Anablume.

Harman, G. (2011). The quadruple object. Winchester: Zero Books.

Heidegger, M. (1971). Building, dwelling, thinking (A. Hofstadter, Trans.). In M. Heidegger (Ed.), Poetry, language, thought. New York, NY: Harper \& Row.

Heidegger, M. (1973). Sobre o humanismo (E. Stein, Trans.). São Paulo, SP: April.

Heidegger, M. (2003). L'arte e lo spazio. Genoa, Italy: Il Melangolo.

Heidegger, M. (2012). La historia dell'essere. Milan, Italy; Marinotti.

Índios Krahôs recuperam a machadinha. (1986a, June 12). Folha de São Paulo. Retrieved from https://documentacao.socioambiental.org/noticias/ anexo_noticia/20617_20110711_143531.pdf

Índios podem ter machadinha se o museu receber uma réplica. (1986b, May 29). Folha de São Paulo.

Latour, B. (2012). Reagregando o social: uma introdução à teoria do Ator-Rede. São Paulo, SP: EDUSC. 
Latour, B. (2004). Politcs of nature: How to do science in a democracy. London, UK: Harvard University Press.

Lemos, A. (2008). Mídia locativa e territórios informacionais. In P. Arantes \& L. Santaella (Eds.), Estéticas tecnológicas. São Paulo, SP: Educ.

Lovelock, J. (2007). Gaia: Um novo olhar sobre a vida na Terra. Lisbon, Portugal: Edições 70.

Marchesini, R. (2012). Post-human. Verso nuovi modelli di esistenza. Turin, Italy: Bollati Boringhieri.

Meillassoux, Q. (2008). After finitude. An essay on the necessity of contingency. London/New York: Continuum.

Melatti,J. C. (1963). O mito e o xamã. Revista do Museu Paulista, 14, 60-70.

Melatti, J. C. (1970). O sistema social (Doctoral thesis). Universidade de Brasília, Brasília.

Melatti, J. C. (1974). Contos de guerra dos índios Craôs. Série Antropologia, $n^{\circ}$ 8. Brasilia: Departamento de Ciências Sociais, Universidade de Brasília.

Melo, J. H. T. (2010). Kàjré: a vida social de uma machadinha Krahô (Master's thesis). Universidade Federal do Rio Grande do Norte, Natal.

Morim, A. G. (2013). Uma biografia do Kàjre, a machadinha Krahô. In J. R. S. Gonçalves, R. S. Guimarães, N. P. Bitar (Eds.), A alma das coisas. Patrimônios, materialidade e ressonância (pp. 185-210). Rio de Janeiro, RJ: Mauad X: Faperj.

Perniola, M. (1997). Estetica del novecento. Bologna: Il Mulino. 
Ribeiro Durham, E. (1986, May2). A Universidade e a machadinha. Acervo ISA. Retrieved from https://documentacao.socioambiental.org/ noticias/anexo_noticia/20586_20110707_185808.pdf

Santaella, L. (2008). Mídias locativas: a internet móvel de lugares e coisas. Revista FAMECOS: Mídia, Cultura e Tecnologia, (35), 95-191. doi: 10.15448/1980-3729.2008.35.4099.

Serres, M. (2001). O Contrato Natural. Lisboa, Portugal: Instituto Piaget.

Simondon, G. (2009). La individuación. Buenos Aires, Argentina: Editorial Catus/La Cebra Ediciones.

Stengers, I. (2007). La proposition cosmopolitique. In J. Lolive \& O. Soubeyran (Eds.), The emergence des cosmopolitiques (pp. 45-68). Paris, France: La Découverte.

Viveiros De Castro, E. (2015). Metafísicas canibais. São Paulo, SP: Cosac \& Naify.

Viveiros De Castro, E. (2013) A inconstância da alma selvagem. São Paulo, SP: Cosac \& Naify.

Viveiros De Castro, E. (1996). Os pronomes cosmológicos e o perspectivismo ameríndio. Mana, 2(2), 115-144. doi: 10.1590/S010493131996000200005. 